\title{
Corruption Distance and US Foreign Direct Investment Outflows
}

\author{
Mohammad Refakar ${ }^{1}$ \\ ${ }^{1}$ Business School, Unievrsity of Sherbrooke, Sherbrooke, Canada \\ Correspondence: Mohammad Refakar, Business School, Unievrsity of Sherbrooke, Sherbrooke, QC, J4K 0A8 \\ Canada. Tel: 1- 450 463-1835 ext. 62362. E-mail: Mohammad.Refakar@USherbrooke.ca
}

Received: May 3, 2021

Accepted: June 3, 2021

Online Published: June 15, 2021

doi:10.5539/ijef.v13n7p98

URL: https://doi.org/10.5539/ijef.v13n7p98

\begin{abstract}
Corruption, defined as the misuse of public power for private gains, is a problem for many emerging and developing countries. Corruption increases the poverty and reduces growth and investment. This paper aims to analyze the relationship between corruption in the host country and the US foreign direct investment towards that country. I use two measures for corruption: The Corruption Perceptions Index and the corruption distance, which is the absolute difference of the corruption in the host and the US. Using a sample of 47 countries that receive the US foreign direct investment, I find that corruption is a strong determinant of US FDI outflows and the US investors are reluctant to invest in corrupt countries. Moreover, corruption distance has a negative effect on US FDI since as the distance in corruption increases, we observe less US FDI towards the host country.
\end{abstract}

Keywords: corruption, corruption distance, foreign direct investment

JEL: D73, F21, G11.

\section{Introduction}

Corruption is one of the most ancient problems of mankind and it is omnipresent (Shleifer \& Vishny, 1993; Bardhan, 1997). Common sense views corruption as an impediment to growth, development and investment. The literature which investigates the consequences of corruption, posits that high level of corruption is associated with slow economic growth and low investment. These hypotheses are supported by empirical studies. In a seminal paper, Mauro (1995) reports empirical evidence for a negative correlation between corruption and the ratio of inward investment to gross domestic product (GDP), as well as economic growth, in a cross-section of countries. Drabek and Payne (2002) argued that corruption has a detrimental effect on FDI attractiveness. Rock and Bonnett (2004) argue that corruption reduces investment in most developing countries and particularly in small open economies. This body of evidence propose that corruption is harmful to economic growth, foreign direct investment and development of a country. As a result, international organizations (e.g. the IMF, the World Bank, the UN or the OECD) gave the fight against corruption high priority. Many consequent studies broaden his results and some focus on the effects of host country corruption on foreign direct investment (FDI) and find the deterrent role of corruption on inward FDI (Hines, 1995; Henisz, 2000; Wei, 2000; Habib \& Zurawicki, 2001, 2002; Seldadyo \& Haan, 2011; Qian \& Sandoval-Hernandez, 2016; Brada et al., 2019).

FDI is defined as an investment involving a long-term relationship and reflecting a long-term interest and control of a resident entity in one economy other than that of investor (Sanyal \& Samanta, 2008). Since FDI boosts the economic growth and development through technology transfers and spillovers, many countries have long-term policies to attract investors. Grosse and Trevino (1996) and Chen and Chen (1998) classify the determinants of cross-border FDI into three categories: (1) firm-specific factors, (2) location-specific factors, and (3) measures of the relationship between the source and host countries. Location factors such as market size, borrowing costs, unit labour costs, and institutional and political stability, are critical for the firm's investment decision (Click, 2005; Sanyal \& Samanta, 2008; Oseghale \& Nwachukwu, 2010; Bekaert et al., 2014). Corruption is determined by a country's institutional and political environment; thus, high levels of corruption reduce the locational attractiveness and have a negative impact on investors' decision to invest. Habib and Zurawicki (2002) state that "a corrupt economy does not provide open and equal market access to all competitors. Price and quality become less important than access, since bribery takes place in secret. Payments to the host country officials do not have a market value and, hence, raise the cost of goods when compared to a competitive market. This can be a major disincentive for foreign investors" (p. 293). Hines (1995) finds that corruption in the host country significantly reduces inward FDI. Drabek and Payne (2002) investigate the effect of non-transparency, which consists of 
corruption, weak protection of property rights, and poor governance, on FDI. They report that non-transparency negatively impacts FDI. Wei (2000) finds a significant and negative effect of corruption on FDI, using data of the 1990s from 12 source countries to 45 host countries.

A distinctive feature of corruption is its "lock-in" effect. Once in the game, it is very difficult to get out of it. Firms opening their doors for corruption may find it difficult to resist demands for bribery payments in the future (Rose-Ackerman, 1999). Additionally, firms with a reputation for bribing are more likely to receive demands for higher bribe payment by corrupt officials, sometimes even for the services that are normally offered for free. Moreover, the threat of mutual denunciation makes the partners tied to each other even after the bribery transaction. This constant engagement in corrupt actions raises the barriers to entry and exit of corrupt markets for foreign investors. Moreover, Wei (2000) suggest that severe corruption has a similar effect to increasing the host country tax rate. Corruption in the host country increases the cost of entry and acts as a barrier, reducing the profits of firms and therefore lowering a firm's incentives to invest in that country.

Since the US was one of the first countries to ratify a federal law (Foreign Corrupt Practice Act - FCPA) in 1997 to avoid corruption and bribery, the US investors are corruption sensitive and do not intend to invest in corrupt countries. The aim of this article is to analyze and to test the hypothesis that the US FDI outflows are negatively affected by corruption in the host country. Using a sample of 47 countries spanning from 2000 to 2015 (16 years), I find that corruption is indeed a determinant of FDI location choice. The more corrupt a country, the less US FDI it receives. The rest of the paper explains the data and models used in this article followed by the results of regression estimations. Then I conclude with a conclusion.

\section{Data}

The data has been complied from different sources. The US FDI outwards are downloaded from US Bureau of Academic Analysis, which publishes the data related to US foreign direct investment. I analyze 47 countries in the sample that received the US FDI. The data spans from 2000 to 2015, with a total observation of $752(47 * 16)$. Corruption Perception Index is downloaded from Transparency International. The Population, Unemployment rate, Inflation, Trade intensity (Trade \% of GDP), Government expenditure (General government final consumption expenditure, \% of GDP), GDP and GDP growth are downloaded from World Bank Open Data. The Geographical distance in kilometres and the Common religion dummy is retrieved from CEPII (Research and expertise on the world economy). Colonial history is a dummy variable that takes the value of one if the country was a former colony after 1825 and zero otherwise (Barro \& Lee, 1994). And finally, Political rights variable is retrieved from Freedom House (freedomhouse.org).

\subsection{The Model}

I use the gravity model of trades as the benchmark model for the multivariate regressions. According to gravity model of trades, bilateral trades are positively related to the sizes of the countries and negatively related to the physical distance of them (Hamilton \& Winters, 1992; Brainard, 1993; Markusen \& Venables, 2000; Anderson \& Wincoop, 2003). Following the literature, I add Log GDP and Log Population to control for the size of the economy and the Log Geographical Distance to control for the distance (Wei, 2000; Habib \& Zurawicki, 2002; Head \& Ries, 2008; Razin et al., 2005, Brada et al., 2019). However, the literature expands the notion of distance to other variables such as cultural distance as well as corruption distance (Habib \& Zurawicki, 2002). I use corruption in the host country and the corruption distance, defined as the absolute difference of CPI in the US and in the host. GDP growth controls for the attractiveness of the country and higher GDP growth increases the incentives to invest and is a proxy for the change in macroeconomic conditions of the host (Rossi \& Volpin, 2004). Unemployment rate is a proxy for labour availability of the host country (Habib \& Zurawicki, 2002; Godinez \& Liu, 2015). Trade intensity encourages FDI because countries open to international trades provide a good platform for global business operations. Furthermore, having a common language with the US can simplify FDI between the country pairs. The government expenditure activities in areas such as infrastructure, social, and economic activities help the economy or the GDP to grow which helps the economic performance. Moreover, countries with more political rights attract more investors. The inflation rate controls for macroeconomic stability of the host country and an indicator of the ability of government and the central bank to control the budget and money supply. I use the following econometric model to test the hypotheses:

$$
F D I_{i, t}=\alpha_{0}+\beta_{1} \text { Cor }_{i, t}+\beta_{2} \text { CorDis }_{i, t}+\gamma_{\gamma} X_{i, t}+\lambda_{t}+\theta_{i}+\varepsilon_{i, t}
$$

Where FDI $\mathrm{I}_{\mathrm{i}, \mathrm{t}}$ is the natural logarithm of the level of US foreign direct investment to the host country $\mathrm{i}$ in year $\mathrm{t}$; $\mathrm{Cor}_{\mathrm{i}, \mathrm{t}}$ is the CPI of the host country $\mathrm{i}$ in year $\mathrm{t}$; $\operatorname{CorDis}_{\mathrm{i}, \mathrm{t}}$ is the corruption distance which is defined as the absolute difference in CPI of the US and host country $i$ in year $t$; $X_{i, t}$ is the vector of control variables, $\beta_{1}, \beta_{2}$ and $y$ are the parameters to be estimated; $\alpha_{0}$ is intercept; $\varepsilon_{\mathrm{i}, \mathrm{t}}$ is normal error terms with mean zero and variance $\sigma_{\varepsilon}^{2}$. 


\section{Results}

\subsection{Descriptive Statistics}

Table 1. Summary statistics

\begin{tabular}{|c|c|c|c|c|c|}
\hline Variable & Obs & Mean & Std. Dev. & Min & Max \\
\hline \multicolumn{6}{|l|}{ Dependent variables } \\
\hline US outward FDI (US\$ million) & 720 & 43455.49 & 86665.02 & -608 & 858102 \\
\hline \multicolumn{6}{|l|}{ Variables of interest } \\
\hline Corruption perception index (CPI) & 749 & 55.56407 & 24.74826 & 10 & 100 \\
\hline Corruption distance & 752 & 26.30812 & 17.10771 & 0 & 78 \\
\hline \multicolumn{6}{|l|}{ Control variables } \\
\hline Host Log GDP & 747 & 26.44905 & 1.379087 & 22.20843 & 30.0167 \\
\hline Host GDP Growth & 751 & 3.260874 & 3.734052 & -17.669 & 33.73578 \\
\hline Geographic Distance & 752 & 8.967027 & 0.557972 & 6.602646 & 9.703274 \\
\hline Host Unemployment rate & 746 & 7.475742 & 4.532787 & 0.5967 & 27.2 \\
\hline Host Log Population & 752 & 17.20656 & 1.375754 & 15.15187 & 21.03897 \\
\hline Host Inflation Rate & 748 & 40.482 & 893.4746 & -6.75 & 24411.03 \\
\hline Colonial History & 752 & 0.595745 & 0.491074 & 0 & 1 \\
\hline Common Language with US & 752 & 0.255319 & 0.436331 & 0 & 1 \\
\hline Political Rights & 752 & 2.421543 & 1.745213 & 1 & 7 \\
\hline Host Gov Expenditure/GDP & 716 & 15.44041 & 6.157105 & 1.93288 & 31.59911 \\
\hline Host Trade Intensity & 729 & 86.06798 & 73.47989 & 20.25789 & 455.2767 \\
\hline
\end{tabular}

Table 1 presents summary statistics of the corruption, corruption distance, US outward FDI, and other control variables. There are 717 observations for the US FDI outflows because in 35 cases, US FDI to a specific country on a specific year is not reported by the US Bureau of Economic Analysis. The US FDI outflows have a maximum of 858 million dollars to Netherlands in 2015, and a minimum of 2 million dollars in 2004 to Greece. The corruption perception index (CPI) has a maximum of 100 for Finland in 2000 and a minimum of 10 for Nigeria in 2001. The corruption distance has a maximum of 78 between the US and Pakistan in 2000 and a minimum of 0 between USA and Ireland, Japan, Austria and some other countries. China had a 10 trillion GDP in 2015 and Zimbabwe had the lowest GDP in the sample of only 4 billion in 2008. Nigeria in 2004 had the highest GDP growth of $33 \%$ and Zimbabwe had the lowest GDP growth of $-17 \%$ in 2008. China, with a population of about 1.37 billion, is the most populated country in the sample, and Ireland, with a population of about 3.7 million, is the least populated country in the sample. Canada is the closest country to the US with a distance of $737 \mathrm{~km}$ between the two capitals, and the farthest country is Indonesia with a distance of $16,371 \mathrm{~km}$.

Table 2. Pairwise correlation matrix

\begin{tabular}{|c|c|c|c|c|c|c|c|c|c|c|c|c|c|}
\hline & 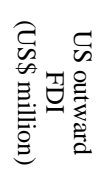 & O્ & 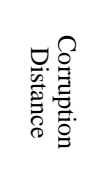 & 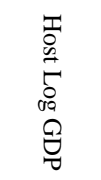 & 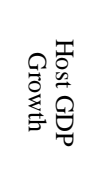 & 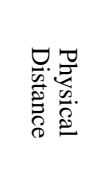 & 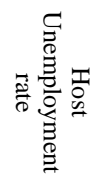 & 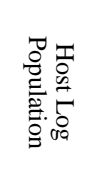 & 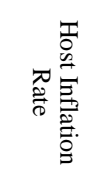 & 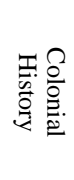 & 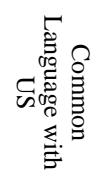 & 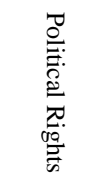 & 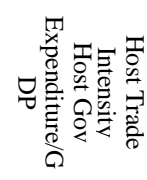 \\
\hline $\begin{array}{l}\text { US outward FDI } \\
\text { (US\$ million) }\end{array}$ & 1 & & & & & & & & & & & & \\
\hline CPI & 0.3718 & 1 & & & & & & & & & & & \\
\hline Corruption Distance & -0.3305 & -0.8642 & 1 & & & & & & & & & & \\
\hline Host Log GDP & 0.3451 & 0.2838 & -0.4006 & 1 & & & & & & & & & \\
\hline Host GDP Growth & -0.1329 & -0.2347 & 0.2282 & -0.0619 & 1 & & & & & & & & \\
\hline Geographic Distance & -0.3158 & -0.0739 & 0.062 & -0.056 & 0.2341 & 1 & & & & & & & \\
\hline Host Unemployment rate & -0.1275 & -0.1836 & 0.0863 & -0.1135 & -0.1415 & -0.0612 & 1 & & & & & & \\
\hline Host Log Population & -0.0579 & -0.5943 & 0.4646 & 0.4556 & 0.2517 & 0.1272 & 0.0108 & 1 & & & & & \\
\hline Host Inflation Rate & -0.058 & -0.0595 & 0.0619 & -0.1211 & -0.0789 & -0.063 & -0.0204 & -0.0221 & 1 & & & & \\
\hline Colonial History & -0.1094 & -0.4368 & 0.4523 & -0.4196 & 0.2562 & 0.0661 & 0.0344 & 0.136 & 0.0351 & 1 & & & \\
\hline Common Language with US & 0.1022 & 0.1202 & -0.0462 & -0.0486 & 0.1604 & 0.1722 & 0.0325 & -0.0076 & -0.0238 & 0.38 & 1 & & \\
\hline Political Rights & -0.219 & -0.5726 & 0.5971 & -0.4056 & 0.267 & 0.1712 & -0.0444 & 0.2877 & 0.1076 & 0.39 & 0.0071 & 1 & \\
\hline Host Gov Expenditure/GDP & 0.1167 & 0.418 & -0.3822 & 0.1413 & -0.233 & -0.1878 & 0.1252 & -0.2758 & -0.0783 & -0.42 & -0.1482 & -0.3681 & 1 \\
\hline Host Trade Intensity & 0.1946 & 0.3686 & -0.3232 & -0.1512 & 0.0623 & 0.2076 & -0.2184 & -0.4355 & -0.0027 & 0.08 & 0.2872 & 0.1728 & $-0.1178 \quad 1$ \\
\hline
\end{tabular}


Table 2 presents the pairwise correlation matrix between the variables used in this article. The dependent variable US FDI does not show any high correlation to any variables. None of the other variables are highly correlated with each other which eliminates the possibility of multicollinearity in this study.

\subsection{Determinants of Foreign Direct Investment}

To analyze the effects of corruption on US outward FDI, I use a multivariate regression framework. I aim to analyze how corruption measures by CPI and the corruption distance can affect the level of US FDI towards that country. Because I am interested in the effects of corruption on US FDI outflows and how changes corruption as well as corruption distance can influence US outward FDI, I use a multivariate regression model. The dependent variable is the natural logarithm of the level of US FDI towards receiving country and the variables of interest are corruption and corruption distance. I also use several control variables that are suggested by the literature as a determinant of outward FDI.

Table 3 presents the regression estimates of the determinants of US FDI outflows. In model one, I use the corruption of the host country as the variable of interest and in model two, the variable of interest is corruption distance. The model one shows that CPI, measured by the perceptions of corruption in the host country is a strong determinant of US FDI outflows. The CPI coefficient is positive and strongly significant. This means as the CPI increases (less corruption), the flow of FDI also increases. In other words, US investors are reluctant to invest in a corrupt country. In our sample, an increase of one unit of CPI, increases the FDI by 1 million dollars. All the control variables also have the expected sign and mostly significant. GDP is positive and strongly significant, and Geographic distance's coefficient is negative and significant. These two variables which are the variables that are recommended by the gravity model, confirm the use of the gravity model as the benchmark model. Political rights in the host country is negative and significant. This confirms that US investors do not invest in countries where political rights are not respected. Trade intensity is significant and positive which means that this variable also positively affects the US outward FDI. The R-squared of the model one is 0.8 which means that the model fits the data.

Table 3. OLS analysis of the outward US foreign direct investment

\begin{tabular}{|c|c|c|}
\hline & (1) & $(2)$ \\
\hline \multicolumn{3}{|l|}{ Variables of interest } \\
\hline CPI & $0.02 * * *(5.72)$ & \\
\hline Corruption Distance & & $-0.02 * * *(-3.14)$ \\
\hline \multicolumn{3}{|l|}{ Control variables } \\
\hline Host Log GDP & $1.13 * * *(21.36)$ & $1.22 * * *(24.83)$ \\
\hline Host GDP Growth & $-0.01(-0.39)$ & $-0.01(-0.26)$ \\
\hline Geographic Distance & $-0.61 * * *(-10.52)$ & $-0.61 * * *(-10.99)$ \\
\hline Host Unemployment rate & $-0.02 *(-1.82)$ & $-0.03 * * *(-3.4)$ \\
\hline Host Log Population & $-0.01(-0.04)$ & $-0.15^{* * *}(-2.83)$ \\
\hline Host Inflation Rate & $0.01(0.1)$ & $0.01(0.23)$ \\
\hline Colonial History & $0.76^{* * *(8.6)}$ & $0.73 * * *(7.95)$ \\
\hline Common Language with US & $0.02(0.12)$ & $0.15 *(1.78)$ \\
\hline Political Rights & $-0.15^{* * *}(-4.41)$ & $-0.15 * * *(-3.87)$ \\
\hline Host Gov Expenditure/GDP & $-0.03^{* *}(-2.53)$ & $-0.02(-1.59)$ \\
\hline Host Trade Intensity & $0.01 * * *(10.67)$ & $0.01 * * *(9.88)$ \\
\hline Constant & $-16.32 * * *(-17.67)$ & $-15.25^{* * * *}(-14.65)$ \\
\hline Observations & 670 & 670 \\
\hline $\mathrm{R}^{2}$ & 0.80 & 0.80 \\
\hline
\end{tabular}

Note. This table presents estimates of OLS analysis of the US foreign direct investment outflows. The dependent variable is the logarithm of the amount of US foreign direct investment towards each country. Heteroskedasticity-corrected t-statistics are in parentheses. $* * *, * *$, and $*$ denote statistical significance at the $1 \%, 5 \%$, and $10 \%$ levels, respectively.

In the second model, I regress the US outward foreign direct investment on corruption distance and other control variables. The results are very interesting. Corruption distance has a negative and significant coefficient. This means that as the distance in corruption increases, the amount of US FDI decreases. In other terms, US investors do not want to invest in countries with which, they have a big difference of corruption.

Other control variables are significant and have the expected signs. GDP has a positive and significant 
coefficient while Geographical distance has a negative and significant coefficient which confirms the relevance of gravity model in this article. Common language is positive and significant, which means that countries with the same language as the US, receive more FDI.

To be able to understand better the role of the corruption distance, in Table 4, I divide the sample into two subsamples, and I analyze the effects of corruption distance. In Model one, the subsample consists of the countries that their CPI is lower than the US (more corrupt). Model two represents the subsample of countries that their CPI is higher than the US (less corrupt). With these analyses, we can compare the effect of corruption distance for countries that have higher and lower corruption than the US.

Table 4. OLS analysis of the outward US foreign direct investment (less/more corrupt)

\begin{tabular}{lcc}
\hline & $(1)$ & $(2)$ \\
& More corrupt & Less corrupt \\
\hline Variable of interest & & $0.02 *(1.79)$ \\
Corruption Distance & $-0.02 * * *(-3.64)$ & \\
Control variables & & $1.17 * * *(7.08)$ \\
Host Log GDP & $1.06 * * *(17.49)$ & $0.01(0.16)$ \\
Host GDP Growth & $-0.01(-0.21)$ & $-0.3 * * *(-3.08)$ \\
Geographic Distance & $-1 * * *(-9.54)$ & $-0.18^{* * *(-5.52)}$ \\
Host Unemployment rate & $0.01(0.92)$ & $0.1(0.58)$ \\
Host Log Population & $0.15 * *(2.02)$ & $-0.19 * * *(-4.19)$ \\
Host Inflation Rate & $-0.01(-0.7)$ & $1.28 * *(2.26)$ \\
Colonial History & $0.65 * * *(6.1)$ & $0.02(0.02)$ \\
Common Language with US & $0.07(0.57)$ & $-0.96 * * *(-5.62)$ \\
Political Rights & $-0.15^{* * *(-4.49)}$ & $0.01(0.67)$ \\
Host Gov Expenditure/GDP & $-0.03 * * *(-3.27)$ & $0.02 * * *(8.43)$ \\
Host Trade Intensity & $0.02 * * *(9.99)$ & $-19.51 * * *(-6.89)$ \\
Constant & $-12.79 * * *(-9.31)$ & 217 \\
Observations & 441 & 0.75 \\
$\mathrm{R}^{2}$ & 0.81 & \\
\hline
\end{tabular}

Note. This table presents estimates of OLS analysis of the US foreign direct investment outflows. The dependent variable is the logarithm of the amount of US foreign direct investment towards each country. ***,**, and $*$ denote statistical significance at the $1 \%, 5 \%$, and $10 \%$ levels, respectively.

For the model one (more corrupt countries), the corruption distance is negative and significant, as Table 3 . This means that corruption distance for countries that are more corrupt than the US discourages the US investors. However, the coefficient changes the sign in model two which means the distance of corruption increases FDI outflows to the counties that are less corrupt than the US.

GDP is significant and positive and Geographical distance is negative, confirming the use of the gravity model. All the other control variables are mostly significant and have the expected sign.

\section{Conclusion}

Corruption in an impediment to growth and investment and corrupt countries receive less investment. US investors are corruption averse because of the Foreign Corrupt Practice Act. Therefore, they do not tend to invest in a corrupt country. To study the effect of corruption on the US foreign direct investment, I use a multivariate regression model for sample of 47 countries over 16 years. I analyze two variables of interest: the corruption in the host country and the corruption distance between the US and the host country. I find that corruption in the host country is a strong determinant of US foreign direct investment outflows. Indeed, corrupt countries receive less US FDI. Corruption distance is another determinant of US FDI. As the corruption distance increases, the amount of US FDI decreases.

\section{References}

Anderson, J. E., \& Van Wincoop, E. (2003). Gravity with Gravitas: A Solution to the Border Puzzle. American Economic Review, 93(1), 170-192. https://doi.org/10.1257/000282803321455214

Bardhan, P. (1997). Corruption and Development: A Review of the Issues. Journal of Economic Literature, 35(3), 1320-1346. https://doi.org/10.4324/9781315126647-30 
Barro, R. J., \& Lee, J. W. (1994, June). Sources of economic growth. In Carnegie-Rochester conference series on public policy (Vol. 40, pp. 1-46). North-Holland. https://doi.org/10.1016/0167-2231(94)90002-7

Bekaert, G., Harvey, C. R., Lundblad, C. T., \& Siegel, S. (2014). Political Risk Spreads. Journal of International Business Studies, 45(4), 471-493. https://doi.org/10.1057/jibs.2014.4

Brada, J. C., Drabek, Z., Mendez, J. A., \& Perez, M. F. (2019). National levels of corruption and foreign direct investment. Journal of Comparative Economics, 47(1), 31-49. https://doi.org/10.1016/j.jce.2018.10.005

Brainard, L. (1993). A Simple Theory of Multinational Corporations and Trade with a Trade-Off Between Proximity and Concentration. Working Paper 4269, National Bureau of Economic Research, Cambridge, MA. https://doi.org/10.3386/w4269

Chen, H., \& Chen, T. J. (1998). Network Linkages and Location Choice in Foreign Direct Investment. Journal of International Business Studies, 29(3), 445-468. https://doi.org/10.1057/palgrave.jibs.8490002

Click, R. W. (2005). Financial and Political Risks in US Direct Foreign Investment. Journal of International Business Studies, 36(5), 559-575. https://doi.org/10.1057/palgrave.jibs.8400157

Drabek, Z., \& Payne, W. (2002). The impact of transparency on foreign direct investment. Journal of Economic Integration, 17(4), 777-810. https://doi.org/10.11130/jei.2002.17.4.777

Godinez, J. R., \& Liu, L. (2015). Corruption Distance and FDI Flows into Latin America. International Business Review, 24(1), 33-42. https://doi.org/10.1016/j.ibusrev.2014.05.006

Grosse, R., \& Trevino, L. (1996). Foreign Direct Investments in the United States: An Analysis by Country of $\begin{array}{lllll}\text { Origin. Journal of International Business } & \text { Studies, }\end{array}$ https://doi.org/10.1057/palgrave.jibs.8490129

Habib, M., \& Zurawicki, L. (2001). Country-Level Investments and the Effect of Corruption: Some Empirical Evidence. International Business Review, 10(6), 687-700. https://doi.org/10.1016/s0969-5931(01)00038-5

Habib, M., \& Zurawicki, L. (2002). Corruption and Foreign Direct Investment. Journal of International Business Studies, 33, 291-307. https://doi.org/10.1057/palgrave.jibs.8491017

Hamilton, C., \& Winters, L. A. (1992). Opening up International Trade with Eastern Europe. Economic Policy, 14, 77-116. https://doi.org/10.2307/1344513

Head, K., \& Ries, J. (2008). FDI as an Outcome of the Market for Corporate Control: Theory and Evidence. Journal of International Economics, 47(1), 2-20. https://doi.org/10.1016/j.jinteco.2007.04.004

Henisz, W. (2000). The Institutional Environment for Multinational Investment. Journal of Law, Economics and Organization, 16(2), 334-364. https://doi.org/10.1093/jleo/16.2.334

Hines, J. (1995). Forbidden Payment: Foreign Bribery and American Business. NBER Working Paper 5266. https://doi.org/10.3386/w5266

Markusen, J. R., \& Venables, A. J. (2000). The Theory of Endowment, Intra-Industry and Multinational Trade. Journal of International Economics, 52(2), 209-234. https://doi.org/10.1016/s0022-1996(99)00055-0

Mauro, P. (1995). Corruption and Growth. Quarterly Journal of Economics, 110(3), 681-712. https://doi.org/10.2307/2946696

Oseghale, B. D., \& Nwachukwu, O. C. (2010). Effect of the Quality of Host Country Institutions on Reinvestment by United States Multinationals: A Panel Data Analysis. International Journal of Management, 27(3), 497-510.

Qian, X., \& Sandoval-Hernandez, J. (2016). Corruption distance and foreign direct investment. Emerging Markets Finance and Trade, 52(2), 400-419. https://doi.org/10.1080/1540496x.2015.1047301

Razin, A., Sadka, E., \& Tong, H. (2005). Bilateral FDI Flows: Threshold Barriers and Productivity Shocks. Working Paper 11639, National Bureau of Economic Research, Cambridge, MA. https://doi.org/10.3386/w11639

Rock, M., \& Bonnett, H. (2004). The comparative politics of corruption: Accounting for the East Asian paradox in empirical studies of corruption, growth and investment. World Development, 32(6), 999-1017. https://doi.org/10.1016/j.worlddev.2003.12.002

Rose-Ackerman, S. (1999). Corruption and Government, Causes, Consequences and Reform. Cambridge, UK: Cambridge University Press. https://doi.org/10.1017/cbo9781139175098 
Rossi, S., \& Volpin, P. (2004). Cross-country Determinants of Mergers and Acquisitions. Journal of Financial Economics, 74, 277-304. https://doi.org/10.1016/j.jfineco.2003.10.001

Sanyal, R., \& Samanta, S. (2008). Effect of Perception of Corruption on Outward US Foreign Direct Investment. Global Business and Economics Review, 10(1), 123-140. https://doi.org/10.1504/gber.2008.016831

Seldadyo, H., \& De Haan, J. (2011). Is corruption really persistent? Pacific Economic Review, 16(2), $192-206$. https://doi.org/10.1111/j.1468-0106.2011.00542.x

Shleifer, A., \& Vishny, R. (1993). Corruption. The Quarterly Journal of Economics, 108, $599-617$. https://doi.org/10.2307/2118402

Wei, S. J. (2000). How Taxing is Corruption on International Investors. Review of Economics and Statistics, 82, 1-11. https://doi.org/10.1162/003465300558533

\section{Copyrights}

Copyright for this article is retained by the author(s), with first publication rights granted to the journal.

This is an open-access article distributed under the terms and conditions of the Creative Commons Attribution license (http://creativecommons.org/licenses/by/4.0/). 